\title{
America and Iran-Pakistan-India (IPI) Gas Pipeline
}

\author{
Bhat Mukhtar Ahmad
}

Aligrah Muslim University, India.

Received 22 April, 2014; Accepted 3 September, 2014

\begin{abstract}
India and Iran share a historical and long term economic relation that has formed the basis of close bilateral relationship. In contemporary World politics, energy resources play an important role and are considered as the engines of economic growth and development for a country. India's growing energy demand and Iran's vast energy resources make the two nations natural economic partners. For India, Iran becomes attractive because it occupies second and fourth place among the countries having the highest reserves of gas and oil in the whole world. Iran, on the other hand, needs substantial investments not only in its oil and gas industry but in educational, health, defence and in technological sector as well. The sanctions imposed by the West particularly by United States of America have made it difficult for Iran to emerge as a major regional power on the basis export of gas and oil to its nearest and huge markets (Pakistan and India). This paper examines the Iran-Pakistan-India gas pipeline as a confidence building measure in developing strategic relationship between India, Pakistan and Iran, secondly the nature of American attitude and influence on the relationship between Iran and India particularly in context of the proposed (IPI) Iran, Pakistan and India gas pipeline.
\end{abstract}

Key words: India's growing energy situation, Iranian energy sources and IPI gas pipeline, IPI Gas Pipeline and Regional integration, U.S.'s influence on IPI Project.

\section{INTRODUCTION}

India and Iran have a rich history of civilization going back several millennia. Their bilateral relationship is the continuity of an ancient phenomenon, since the Aryans era and shared common homeland as well as traditions. Historians claim that Indo-Iranians belong to a single family and lived together for many centuries in the pasture land of Central Asia that is known as Oxus valley (India embassy in Tehran, 2014). The Indo-Iranian relationship was given concrete foundation during the period of Mughal rule over India. Mughal rulers not only invited the Iranian architects to India but also the educationalist of that times, who translated important books related to medicine, poetry and religion from Persian language to Hindi language. During the period that both countries enjoyed collateral relations, there were free movement of traders, architects, poets, and educationalist (Haider, 2001). With the appearance of British colonial rule over India ties between the two countries were broken till the independence of India. In post-independence period India and Iran established their formal relations on $15^{\text {th }}$ March 1950 by signing the "Treaty of Friendship" that states "there shall be perpetual

\section{E-mail: mukhtarbhat24@gmail.com}

Author agree that this article remain permanently open access under the tems of the Creative Commons Attribution License 4.0 Intemational Lic ense 
peace and friendship between two Governments of the two countries and their differences shall be settled through ordinary diplomatic channels, by arbitration and by such peaceful means as deemed suitable by them" (Abedi, 1996). However, their emerged various factors like with the creation of Pakistan India and Iran lost the direct land link, out-break of wars in South Asian subcontinent (India-China, India-Pakistan), and the Iran's support to Pakistan as well as Iran's partnership with the West. All these factors became obstacle in transforming their past relations into long term strategic partnership. However it was after the Iranian revolution of 1979 which changed the whole political structure and leadership of Iran, both the countries started looking at opportunities for re-establishing their relations by exchanging the official visits from time to time. It was in April 2001 the visit of then Indian Prime Minister, Mr. Atal Bihari Vajpayee who provided a break-through and opened a new chapter in the history of Indo-Iran relationship. The visit boosted the efforts for developing a close Indo-Iran relationship based on mutual interests like Taliban dominated Afghanistan, independence of Central Republics due to the fall of USSR, the economic interests like export of natural gas, developed technology, investment opportunities in areas like health sector, defence and industrial sector etc. Both the countries have identified mutual interests for developing long term strategic partnership especially in information technology, fertilisers, petrochemical and energy sector etc (Khan, 2008).

In contemporary times, India and Iran have not only deepened this relationship but also expanded it to cover wide ranging political, economic, security as well as science and technological aspects. The importance of Iran for India lies in its geostrategic position, energy resources as well as in providing access to the Central Asian region. Iran can play a pivotal role in a number of regional configurations in the Persian Gulf, Afghanistan and in the Caspian areas for India. Iran ultimately will help India not only in countering expanding Chinese and Pakistan's influence in these areas but also in securing reliable and huge energy sources required for developing its economy and in becoming as well as in playing the role of a regional power. But there are various challenges and issues (role of U.S.A., Iranian Nuclear Program, and Afghanistan, so on) which have become the main factors for the two countries to redesign their foreign policy towards each other.

Since the end of the Cold war, United States has been seeking to establish a permanent global dominance in order to take control of strategically important regions of world and particularly of West Asia region of which Iran is one of the major countries. Iranian nuclear programme and its possible implications for the entire region, its ideological disposition, and its huge oil reserves, strategic and economic importance of the Strait of Hormuz, all these make Iran an important regional actor. While as the policy of United States towards Iran is to undermine the Iranian regime and make it subordinate. United States want to go to any extreme to have an excuse to put the square on Iran either by imposing unilateral sanctions or by the threat of military action. From time to time India became the tool for implementing the policy of United States either due to its national interests or due to the inability of its policy makers in handling the issues efficiently.

\section{India's growing energy situation}

Currently, India is one of the world's fastest growing economies. From the year 2006 and 2010, the India's gross domestic product (GDP) increased at a CAGR (Compound Annual Growth Rate) of $8.2 \%$, while global GDP increased at a CAGR of $4.5 \%$ (World Economic Outlook Database, 2011). The rapid increase in economic activity has been accompanied by rising energy consumption. From 2006 to 2010, India's primary energy consumption increased at a CAGR of $8.3 \%$, from 381.4 million tons of oil equivalent (MTOE) to 524.2 MOTE. Coal, oil and natural gas are major sources of primary energy in India, accounting for 52.9, 29.6 and $10.6 \%$, respectively of the primary energy consumption. However, the country has the world's fourth largest coal reserves. The demand and supply gap of coal has been continuously increasing with domestic production unable to keep pace with the demand. In case of oil and gas the deficit is even more. India holds just $0.7 \%$ of the world's proven oil reserves while accounting for $3.9 \%$ of the global oil consumption. Similarly, the country has $0.8 \%$ of the world's proven natural gas reserves, while accounting for $1.9 \%$ of the worldwide gas consumption which results in India importing nearly $20 \%$ of its natural gas consumed through $\mathrm{LNG}^{1}$. Over the past few years, the country's dependence on imported oil has steadily increased as a result of stagnant domestic production and rising demand. This has significant implications on energy security and the overall financial health of the country. While as Domestic production remained flat, hampered by limited prospectively delays in the commissioning of new projects and declining production from existing maturing fields. Disruption in crude oil supplies has always been a cause of concern for India. The recent upheaval in the Middle East countries especially in Libya and Egypt triggered a drop in crude oil production in the region, resulting increased crude oil prices driving up inflation in India. According to Goldman Sachs, the increase in oil price by US $\$ 10$ per barrel could potentially

\footnotetext{
${ }^{1}$. BP Statistical Review of World Energy 2011 http://www.bp.com/.../bp.../statistical_energy_review_2011/.../statistical_revie Accessed on 13/10/2013.
} 
slow India's GDP growth by $0.2 \%$ and may inflate the current account deficit by $0.4 \%$. The recent depreciation of the rupee raised the cost of crude oil imports for India, which in turn has led to increase in inflationary pressures on the economy. Notably, the import of crude oil and oil products rose from US\$50.3 billion in Financial Year 2006 to US\$115.9 billion in Financial Year 2011. In Financial Year 2012 (till October 2011) imports touched US $\$ 75$ billion. $^{2}$ Over the long run the widening trade deficit may result in the dearth of foreign exchange reserves for the country to deploy in other critical infrastructure and social projects.

As India is one of the fastest growing energy markets in world with the demand continuing to outstrip the supply and the main drivers of energy consumption in India are industrial operations, transportation, and urban and rural household uses. The energy sector in India decides the direction of economic growth, as there is a direct correlation between the two faster economic growths continues to accelerate the demand for energy products. Although Indian government has plans for enhancing the exploitation of its hydro power, nuclear energy, and renewable energy resources the analysis indicates that the impact of these supply side alternatives is minor when compared with the total requirements of commercial energy by 2031. Although, the contribution of nuclear hydro and renewable energy forms together increases by about six times during 2001-31. These sources can at most contribute to a mere $4.5 \%$ of the total commercial energy requirements over the modelling time frame. It is, therefore evident that the pressure on the three conventional energy forms that is coal, oil, and gas will continue to remain high at least in the next few decades. As the world's third largest coal producer, India probably will rely on coal to meet the majority of its energy needs for the foreseeable future. Coal currently provides 60 percent of India's commercial energy consumption. Between 1984 and 2004, coal consumption in India increased from 140 million tons (mt) to over $400 \mathrm{mt}$ annually, growing at a rate of 5.4 percent per year. Of the coal consumed 90 percent is produced domestically while about 10 percent is imported, primarily from Australia and South Africa. However, the adverse effects of coal like global warming are already visible. On the other hand, no doubt India has signed the nuclear agreement with US for overcoming India's energy crisis. But it will put further burden of millions of rupees on the annual budget for developing a single nuclear plant. Further it (nuclear deal) has developed the feeling of insecurity in the minds of large section of population which is the witness of the Union Carbide gas leak in 1984, which killed thousands of people and the persons responsible for the accident

\footnotetext{
2 'India's impending energy crisis. ' India's energy security Key issues impacting the Indian oil and gas sector (FICCI).

http://www.ey.com/Publication/vwLUAssets/Indias energy security/\$FILE/In dia-s energy security.pdf Accessed on 10/12/2012.
}

were let free by the government of India, even the victims struggled for long period for the insufficient compensation, relief and rehabilitation that was given to them by government. Further by enacting the nuclear liability bill Indian government has deepened the feeling of insecurity in the minds of its people by following the same path which led to the Union Carbide accident by (a) fixing the liability of the operator of the nuclear installation in case of accident only 1500 crores at the place were lose could be huge and unimaginable (b) not making the nuclear material supplier responsible for his role in case of nuclear accident due to negligence while supplying the material to the nuclear plant (c) by fixing the maximum period of 10 years for claiming the compensation by the victims (d) Victims are not given right to sue anyone neither the operator nor the supplier (Suvrat and Ramana, 2010). As a result of this now local population protests against the construction of nuclear plants in their areas the latest example is the Kudankulam nuclear plant. So it clearly indicates that natural gas is a preferred option for power generation as well as for the production of nitrogen fertilizer. The availability of natural gas therefore, needs to be facilitated by removing infrastructural constraints. Besides its high end-use efficiency, it is a cleaner fuel and relatively much easier to handle than coal, nuclear material and nuclear plants (Bhat, 2013).

\section{Iranian energy sources and IPI gas pipeline}

In terms of Iran's potential to meet India's rapidly growing energy requirements, Iran has the second largest gas reserves in the world and is seeking to repair damage caused by the Iran and $U$. S. relations and sanctions. Iran hope for an opportunity to exploit its natural gas reserves through the mega-project (Iran, Pakistan and India gas pipeline) that could spur economic prosperity in the provinces where the pipeline ran. The IPI gas pipeline project could transform Iran from being merely an oil producer to a major energy exporter. That ultimately enhances Iran's regional and global stature (Nadeem and von Ochssée, 2009). The projected Iran-Pakistan-India Pipeline (IPI) would stretch 1,724 miles, or 2,775 kilometres, is now under construction to deliver natural gas from Iran to Pakistan. Iran has already completed a 900-kilometre portion of 56-inch diameter pipeline from Assaluyeh to Iran Shehr. The remaining 250 kilometre portion up to the Pakistan border is still under design and is expected to be completed in limited period. In 2012, Pakistan decided to finish the huge pipeline project "at any cost" as it suited Pakistan in odd circumstances. The capacity of the pipeline would be between 8.7 billion cubic meters to 40 billion cubic meters of natural gas per year. It could be raised up to 55 billion cubic meters per year. It is generally believed that gas delivered from Iran would be cheaper than delivered through the proposed Trans-Afghanistan Pipeline (Daheem, 2013). The idea of 
an overland trans- Pakistan pipeline was first proposed in 1989 by Ali Shams Adekani than acting Deputy Foreign Minister of Iran and R.K. Pachauri, the then Director General of the TATA Energy Research Institute in New Delhi (Temple, 2007). It was in 1993 both countries signed Memorandum of Understanding for the project. However, at the earlier stage, the project did not influence many because of Pakistan's initial reluctance to participate in the project. The negative response of Pakistan forced Iran and India to look for other possible options for laying down the pipeline project. Thus they started looking at the options of shallow water pipeline and to the deep sea (sea bed) route for carrying out the project which was much expensive than the overland proposal. While with the change in the government of Pakistan in 1999, it announced its support and participation in the proposed gas pipeline project. At the early stage, both India and Pakistan tried to relate the project with their political issues like India wanted to link it with the transit right for trade with Afghanistan and demanded to remove its restrictions on the bilateral trade. While, Pakistan tried to link it with the resolution of the long pending Kashmir dispute. But later on since 2005, both countries have taken it positively and dropped these demands in order to overcome their energy shortage in their respective countries. In response to the security concern for the gas pipeline raised by India, Pakistan tried to assured both Iran and India that Pakistan would guarantee the security for the project. In a letter, the then petroleum and natural gas minister of Pakistan Usman Aminuddin to his Iranian counterpart assured that Pakistan is prepared to address all concerns of the Indian government. Further Iranian government also assured that if Pakistan at any point of time stopped the gas supplies to India, Tehran will not only stop the supplies to Pakistan but also provide India equal amount of LNG as the same price (Naaaz, 2008).

The prospect of supplying energy to two major markets just next door was an enticing one for Iran. Iran figures very prominently in Indian thinking and is considered highly beneficial to the country's economic future. Piped natural gas poses perhaps the most environmentally and economically cost-effective solution to India's dire energy situation. Not only the IPI pipeline could provide the necessary fuel to India's fertilizer and industrial sectors but also imported gas could help revitalize the defunct electricity market. India's inadequate infrastructure could also benefit from a reliable energy source, which would in turn encourage further foreign investment. As the Planning Commission report on an integrated energy policy has noted, the benefits of a stable power source would eventually be tangible for people at every socioeconomic level of Indian society. Furthermore, since high demand for gas in the private sector will only increase over time, the pipeline is guaranteed to be profitable even if the power sector is eventually able to overcome its dependency on thermal generation (Temple, 2000). For India and Pakistan, the energy needed to fuel economic growth projections could not be fulfilled from a single line (source). Though both states had sought to diversify their energy sources, with natural gas being a crucial component of their strategy and inadequate domestic reserves make those plans imagery without foreign sources. Thus, access to Iran's vast gas reserves by the pipeline project would go in long term towards energy security and Pakistan on its part enjoys an additional incentive of transit fees that can be profitable revenues for boosting its economy.

\section{IPI gas pipeline and regional integration}

Finally, the economic integration inherent in the project offers the possibility of improving strained India-Pakistan political relations. The Project can act as a confidence building measure in the process of integrating whole South Asia particularly India and Pakistan politically, economically, socially and culturally. It can play a vital role not only in resolving the decades old disputes like Kashmir, Siachen and Sir-creek, etc but also provide a peaceful atmosphere as well as bring an end to the arms race between the two countries and ultimately help both the countries in developing their health sector, educational sector, eradicating poverty and unemployment. Despite constraints and series of disputes between India and Pakistan, still the project is still seen by all the three countries as indispensable for their development. Thus IPI gas pipeline can be treated as measure of removing trust deficit between the countries and integrating them in an interdependent whole. On the part of Pakistan by this project it not only would earn a large amount of revenue in the form of transit fee but also would enhance its relations with India in other areas like education, health, information technology, industry and electricity generation as well, which could be helpful for Pakistan in boosting its war torn economy. While on the part of India it would be in its interest to deal with Pakistan economically that not only will weak the anti India forces and propaganda in Pakistan but also push Pakistani government to dismantle the basis of anti-India forces and restrict their activities. IPI also will become an important source of energy for energy starved country like India in long run. The IPI pipeline project would further act as a bridge for both countries (India and Pakistan) to get access to the Persian Gulf and Central Asian countries through Iran. Hence, the IPI project may become a source of regional integration i.e. why some experts called the IPI as the "Peace Pipeline."

\section{U.S.'s influence on IPI gas pipeline}

While as U.S. on the other hand has been applying 
pressure against India and Indian companies which have energy relations with Iran. The most prominent is the Iran-Pakistan-India (IPI) gas pipeline project. Iran and Pakistan have announced that they will go ahead with the project at a bilateral level for the time being. Following the announcement of the recent sanctions against Iran, Washington has told Islamabad that it could be subjected to US sanctions if it went ahead with the pipeline project with Iran. India seems to have delinked from the same though the government has not withdrawn formally. India claims that security and pricing issues with Pakistan and Iran respectively are the main obstacles to its participation, though there has been substantial pressure from US against proceeding with the project. Many in U.S. Congress voice concern about India's relations with Iran and their relevance to U.S. interests. As America's concerns about the Iranian nuclear program have increased, so increased the pressure on India about its participation in gas pipeline project with Iran. The United States has endured India's friendship with Iran as an irritant that could be ignored, the development of the India-Iran energy relationship is a new serious threat. Such a relationship has the potential for revitalizing the Iranian energy sector, as well as opening up new possibilities for the export of oil and gas from the wider Caspian region through Iran. This would undermine the U.S. policy of isolating the Iranian regime in the global polity and economy. The U.S. government reportedly has warned leading oil companies, as well as governments of various nations including India that sanctions are possible if they pursue energy deals with Iran (Steven, 2007). With signing of the U.S.-India civil nuclear pact in 2005. India's relationship with Iran has attracted an even closer scrutiny from America. In March 2005, the US Secretary of state Condoleezza Rice visited India and Pakistan. In New Delhi she said that "the United States had conveyed its concern to India on the gas pipeline. Our ambassador to India has made statements in that regard. So those concerns are well known to India." The US Energy Secretary Samuel Bodman queried his Indian counterpart Murli Deora regarding the pipeline during his visit to India, declaring that Washington needed to stop it. The Sam Lantos, chairman of the foreign Affairs Committee of the US House of Representatives, led a group of US congressmen in writing a letter to the India Prime Minister advising that India pull back not only from the pipeline but from the LNG deal with Iran too (Dietl, 2008). Under American pressure, it has stopped the export, largely by reliance of oil products to Iran and reduced oil imports from Iran. Since 2010 India's payments for its oil import form Iran have become problematic. Its search for payments took India to banks in Germany, Turkey and U.A.E. Even both the countries agreed to partial payment through Indian Rupee. On the American part India was asked to prove its loyalty by providing support to U.S. on the question of Iran's nuclear program at the International
Atomic Energy Agency (IAEA). Some analysts are of the opinion that as large reserves of natural gas have been discovered in India's offshore territory. However, given India's projected huge and growing demand for gas, it will require import of gas, at least in the future. While as the U.S. sponsored Turkmenistan-Afghanistan-Pakistan and India gas pipeline is highly uncertain because of the internal situation of Afghanistan. As long as law and order is not restored in Afghanistan and writ of the government established in the tribal areas of Pakistan and one cannot expect to see the project getting functionalized. Furthermore, the quickly changing internal situation of Afghanistan and the withdrawal of foreign forces from Afghanistan and the chances of Taliban emerging as a strong political power are likely to make the situation more complex. So Iran-Pakistan-India gas pipeline becomes important and reliable source of energy for both India and Pakistan. That may be the reason why India is not officially closing the project of the IPI gas pipeline. As an Indian official who was closely involved with the negotiations said, barring a few issues, everything is in place for the project to be brought to fruition. As and when India feels the time is right for implementing the project, it will do so (Shebonti and Mahtab, 2010). Therefore, it is evident that the IPI pipeline has not gone ahead due to American pressure.

\section{Conclusion}

Energy is one of the most important and efficacious elements in the strategic collaborations between Iran and India. India being a country having second largest population with fast growing economy is in need of new energy sources. In the field of energy, it can be claimed that because of Iran enormous resources of oil supplies it is known as India's one of the most important oil trade partner. The strongest capacities and potentialities for developing relationship between Iran and India lie in energy and trade collaborations. There are sufficient areas through which the mutual collaboration can be transformed into strong mutual integration and energy can be one of the most consequential fields for the expansion of ties. While as, on the other hand United States has left no stone unturned to put pressure on other countries particularly on India not to establish friendly relations with Iran for its personal benefits. Now with the change in the leadership of Iran, the new moderate president Hassan Rouhani has shown flexibility in order to remove the sanctions imposed on Iran for resolving the economic crisis and the issue of Iranian nuclear program peacefully and as per news reports U.S. as well is thinking of easing the sanctions on Iran. So it is time for India to play an active role as a mediator and supporter of negotiations between Iran and United States and on the other to start thinking and approaching to the 
Iranian authorities in order to resolve the issues related the price and transit fee of gas in order to secure and to protect the huge energy sources as well as the historical relations with Iran from the influence of other countries particularly of China.

\section{Conflict of Interests}

The author has not declared any conflict of interests.

\section{REFERENCES}

Abedi AAH (1996). Relations between India and Iran 1947-1979. Iran. J. Int. Affairs 4(7):877-902 http://catalogue.sipri.org/cgi-bin/koha/opacdetail.pl?biblionumber $=52382$

Bhat AM (2013). India and Iran Relations: The Need for Constructive Re-engagement, Country-specific Studies, STUDIES on IRAN Responses, Articles Foreign Policy Research Centre NEW DELHI (India).

Daheem M (2013). 'Pak-Iran gas pipeline agreement' The Frontier Post voice of the Federation, 21/10/2013.

Dietl G (2008). "Transnational Gas Pipeline: Global Context, Indian Experience" India and West Asia in the era of Globalisation by Alam Anwar, publication: New Century publication New Delhi, India p40.

Haider M (2001). Indo-Iran Relations: Historical and Cultural Perspectives, In: Prof. S. M. Waseem (ed.) Indo-Iran Relations. Iran Culture House18, Tilak Marg, New Delhi (India) pp.32-60. http://newdelhi.icro.ir/uploads/indo-iran.pdf

India embassy in Tehran (2014). India and Iran - Age Old Ties. www.indianembassy-tehran.ir/india-iran historica links.php

Khan MN (2008). Vajpayee's Visit to Iran: Indo-Iranian Relations and Prospects of Bilateral Cooperation, 15 Jul. The Institute for Defence Studies and Analyses. Strategic Analysis 25:6
Naaaz F (2008). Indo-Iran Relations: Vital factors in the 1990s. Strategic Analysis, 15 July. The Institute for Defence Studies and Analyses New Delhi, Rautledge, London U.K. 25(2):231-232.

Nadeem S, von Ochssée TB (2009). "The Iran-Pakistan-India Pipeline Project: Cross-Border Gas Pipeline Challenges April," IGU Magazine.

Shebonti RD, Mahtab MAR (2010). "US Sanctions on Iran and their Impact on India". June 21. http://www.idsa.in/system/files/IB USSanctionsonlran.pdf Accessed

Steven RW (2007). "US Cautions Foreign Companies on Iran Deals," Mar. 21, New York Times.

Suvrat R, Ramana MV (2010). The Other Side of Nuclear Liability, April 17. Econ Political Weekly 45:16.

Temple D (2000). The Diplomatic Matrix - Balancing the Objectives of Different Stakeholders APRIL, The Iran-Pakistan-India Pipeline IPCS Research Papers.

Temple D (2007). The Iran-Pakistan-India Pipeline: the intersection of Energy and Politics. April. Institute of Peace and Conflict Studies New Delhi. p.6

World Economic Outlook Database (2011). International Monetary Fund September 